
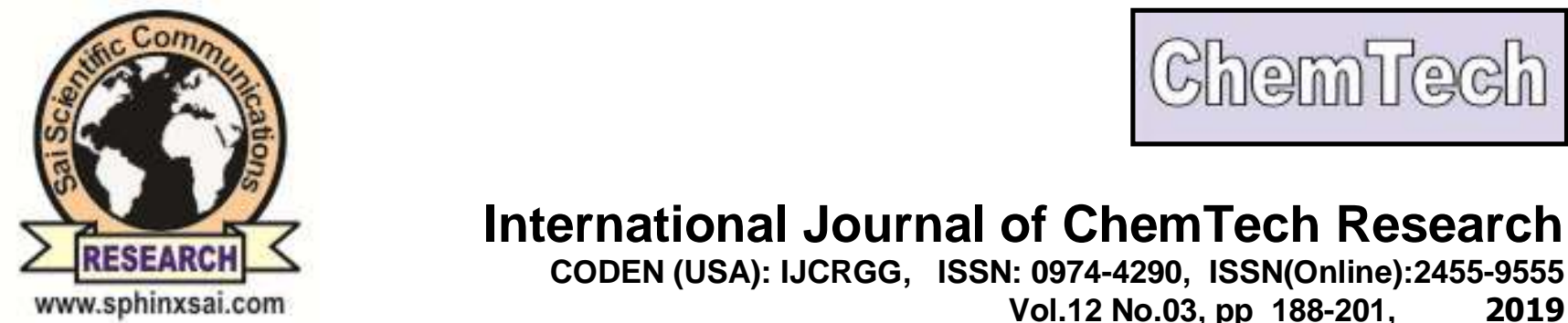

International Journal of ChemTech Research CODEN (USA): IJCRGG, ISSN: 0974-4290, ISSN(Online):2455-9555

Vol.12 No.03, pp 188-201,

2019

\title{
Enhancing Pear Tolerance to Salinity Using Salicylic Acid, Acetylsalicylic Acid and White Willow Extract
}

\author{
Rania Ahmed Mahmoud \\ Deciduous Fruit Research Department, Horticulture Research Institute, \\ Agricultural Research Center, Egypt.
}

\begin{abstract}
Production of pear (Pyrus spp.) as one of the most cultivated and nutritionally vital fruit trees in the world is limited by salinity. The present study aims to alleviate the adverse effects of salinity on growth of 'Le-Conte' pear seedlings by using foliar application of salicylic acid (SA), acetylsalicylic acid (ASA) and natural white willow (Salix alba) extract. Spraying treatments enhanced photosynthetic pigment contents under salt stress conditions, increased proline contents under severe salinity and stimulated antioxidant system. The expression patterns of PbHB1-22 gene revealed that, it is widely involved in responding to salt-induced stress in pear. Effective in vitro inhibition of Salix alba leaves extract against Erwinia amylovora; the causal bacterial pathogen of fire blight, was found to increase in concentration dependent manner.
\end{abstract}

Keywords : Pear, Salinity, Salicylic acid, Acetylsalicylic acid, White willow, Erwinia amylovora.

\section{Introduction:}

Pear (Pyrus spp.) which belongs to family Rosaceae, subfamily Pomoideae; the pome fruits ${ }^{1}$, is one of the most cultivated and nutritionally vital fruit trees in the world. In 2017 according to FAOSTAT, Egypt has a pears production quantity of 64,680 tonnes and area harvested of 10,188 feddan. However, pear production is limited by salinity, where pear trees are generally classified as salt-sensitive ${ }^{2}$.

Salinity is one of the major constraints in the development of irrigated agriculture in humid, arid and semiarid regions all over the world. Every year about $4 \times 10^{4}$ ha of land becomes unfit for agricultural production because of salinization problem. In addition, about $50 \%$ of irrigated area of the world is either salinized or has potential danger at future ${ }^{3}$. Extensive area of land in the arid regions and, particularly, in Egypt became out of cultivation due to salt accumulation ${ }^{4}$. The increased salinization of soils and ground waters in recent decades is considered to be a major problem of agriculture in Egypt and is thought to be a result of the Nile's weak demineralization of the soil due to the absence of flooding ${ }^{5}$. The injurious effects of salt stress on plant activities are associated with decreased water supply in the soil due to osmotic effects ${ }^{6}$ thereby causing physiological drought, nutritional deficiencies, direct toxicity, or combination of all these factors ${ }^{7}$. 
Salix alba (White Willow) of the family Salicaceae, genus Salix is a species of willow with white tone on the underside of the leaves. Ancient people of different civilizations recorded the use of white willow to cure pain and inflammation. The most famous chemical constituents of Salix alba leaves are Salicyl alcohol; Linolenic acid; Galactose, 4,6-O-nonylidene; 4-Acetoxy-3-methoxycinnamic acid; Stearic acid; Stearyl aldehyde $^{8}$. Acetylsalicylic acid is one of the most widely used drugs in the world. Its ancestry the salicylates, including salicin and salicylic acid, are found in the bark and leaves of the willow trees ${ }^{9,10}$.

Salicylic acid (SA; 2-hydroxybenzoic acid) is one of many phenolic compounds (defined as compounds containing a benzene ring bearing one or more hydroxyl groups) that are synthesized by plants. Despite the diversity and ubiquity of plant phenolics, these compounds were traditionally assumed to be rather unimportant, secondary metabolites. However, phenolics were subsequently shown to be involved in many important processes, including lignin and pigment biosynthesis, allelopathy, and the regulation of responses to abiotic and biotic stresses ${ }^{11}$. SA is a critical hormone that plays direct or indirect roles in regulating many aspects of plant growth and development, as well as thermogenesis and disease resistance ${ }^{12}$. Exogenous SA has been shown to affect resistance to biotic (pathogen-associated) stress and tolerance to many abiotic stresses (drought, chilling, heat, heavy metal, UV radiation, and salinity/osmotic stress), as well as multiple aspects of plant growth and development, including seed germination, vegetative growth, flowering, fruit yield, senescence, thermogenesis, stomatal closure, root initiation/growth, photosynthesis, respiration, glycolysis, Krebs cycle, and the alternative respiratory pathway ${ }^{13,14}$.

The present study aims to alleviate the adverse effects of salinity on growth of 'Le-Conte' pear seedlings by using foliar application of salicylic acid (SA), acetylsalicylic acid (ASA) and natural white willow plant extract.

\section{Experimental}

This study was conducted during 2016 and 2017 seasons at the orchard of Horticulture Research Institute, Agricultural Research Center, Giza, Egypt. One-year-old budded seedlings of 'Le-Conte' pear on Pyrus betulifolia rootstock were used as plant experimental materials.

\section{White willow aqueous extract (WAE)}

One hundred grams of White Willow (Salix alba) leaves were washed thoroughly under running tap water followed by distilled water and chopped with $200 \mathrm{ml}$ distilled water $(\mathrm{w} / \mathrm{v})$ by using a domestic blender for $1 \mathrm{~min}$ at average speed. The mixture was macerated during $24 \mathrm{~h}$ at $+4^{\circ} \mathrm{C}$. After that, resulting extract was filtered through double layered Whatman No.4 filter paper. Dilutions were prepared (10 and 20\%). The extract was freshly prepared one day before its foliar application $(25 \mathrm{ml} /$ plant $)$.

Preliminary phytochemical analysis of Salix alba leaves extract ${ }^{8}$ revealed the presence of steroids, alkaloids, phenols, glycosides and tannins.

Forty phytochemical compounds were identified in Salix alba leaves extract using GC-MS ${ }^{8}$. The major compounds were Linolenic acid (16.17\%), 1,2 Cyclohexanediol (12.89\%), Stearic acid (12.66\%), Galactose 4,6-O-nonylidene (11.49\%) and Salicyl Alcohol (7.19\%).

\section{Field experiment}

A randomized complete block design was used with three replicates. Each replicate consisted of 5 pots (35 x $50 \mathrm{~cm}$ ), each containing one seedling. Pots filled with sandy clay soil were planted in February and watered using tap water till the mid of July.

Salinity treatments started July $15^{\text {th }}$ for two months in repetition twice a week as follows:

1- $3000 \mathrm{ppm}$ of $\mathrm{NaCl}$

2- $1500 \mathrm{ppm}$ of $\mathrm{NaCl}$

3- 0 ppm of $\mathrm{NaCl}$ 
Foliar spraying treatments were done once every week during the experiment period as follows:

1- Salicylic acid (SA) at $0.5 \mathrm{mM}$

2- Acetylsalicylic acid (ASA) at $0.5 \mathrm{mM}$

3- White Willow Aqueous Extract (WAE) at 10\%

4- White Willow Aqueous Extract (WAE) at 20\%

5- Water treated control.

Tween 20 was added at $0.05 \%$ as a wetting agent. Survival percentage, growth parameters; green leaves percentage, number of roots and average length of roots $(\mathrm{cm})$, were measured in September $15^{\text {th }}$, then samples of leaves and roots were collected to be used in chemical analysis. The content of total chlorophylls (chlorophyll a and chlorophyll b) and total carotenoids were determined by ${ }^{15,16}$. Proline was assayed according to $^{17}$. Total phenolics were analyzed by the method described by ${ }^{18}$. The antioxidant activity of plant methanol extracts was determined by the method of ${ }^{19}$.

The expression patterns of the PbHB1-22 gene in pear leaves and roots under severe salinity conditions (3000 ppm NaCl) as affected by different foliar applications comparing to control were analyzed by quantitative real-time PCR (qRT-PCR) according to ${ }^{20}$.

In-vitro screening of antibacterial activity against Erwinia amylovora; the causal bacterial pathogen of fire blight, was performed using disc diffusion method ${ }^{21} .0 .5 \mathrm{mM} \mathrm{SA}, 0.5 \mathrm{mM}$ ASA, 10 and 20\% WAE were evaluated as compared to sterile water control.

\section{Statistical analysis.}

Obtained data were statistically analyzed according to $^{22}$ and significant difference was determined using L.S.D. values at $P=0.05$.

\section{Results and Discussion}

\section{Survival percentage}

It's notice that, saline irrigation water up to $3000 \mathrm{ppm} \mathrm{NaCl}$ during the experiment period didn't affect survival percentage of pear seedlings regardless of spraying treatments as compared to those irrigated using tap water. Obtained results are in agreement with ${ }^{2}$ who mentioned that, none of the scions grafted onto Pyrus betulifolia rootstock died under $50 \mathrm{mM} \mathrm{NaCl}$ irrigation up to ten weeks.

\section{Vegetative growth}

Percentage of green leaves gradually decreased as affected by increasing $\mathrm{NaCl}$ concentration in irrigation water (Figure 1). In the same context, increasing irrigation water salinity level negatively affected leave number of pear seedlings as reported by ${ }^{23,24,2}$. All spraying treatments enhanced percentage of green leaves under both levels of saline irrigation water as compared to control during both seasons. Control seedlings recorded lowest green leaves percentages in average; $69.88,70.95 \%$ for first and second seasons, respectively. 


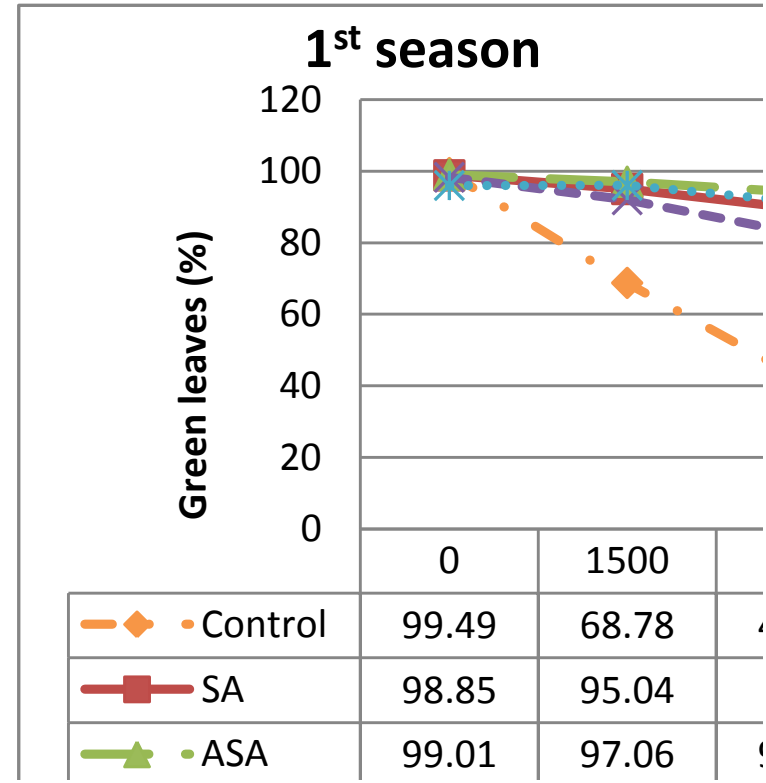

L.S.D. $5 \%$
$\mathrm{NaCl} 1.104$

Treatments 1.426

Interaction 2.470

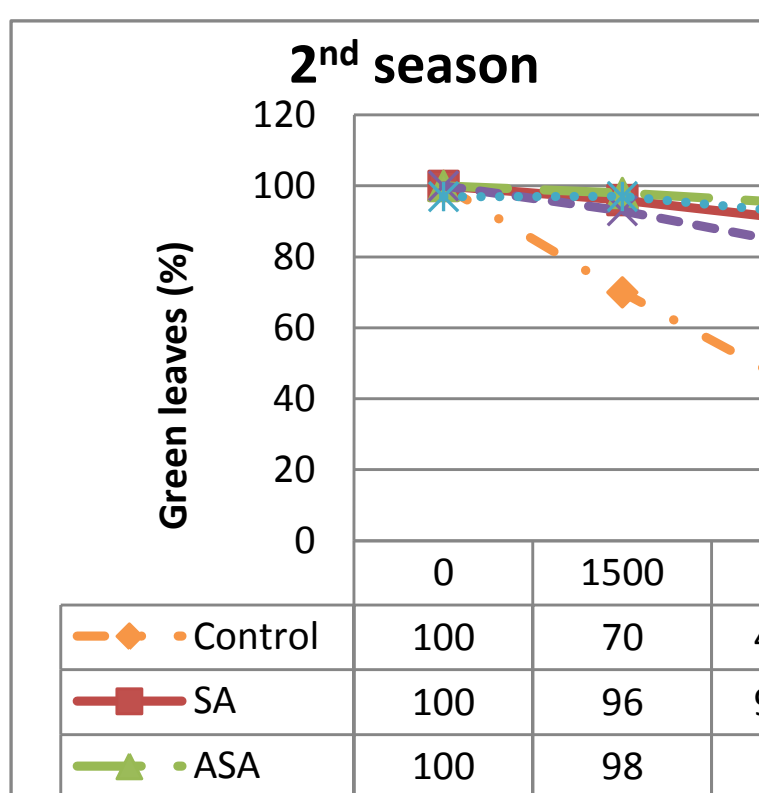

L.S.D. $5 \%$
$\mathrm{NaCl} 1.018$

Treatments 1.314

Interaction 2.276

Figure (1). Effect of irrigation with saline water on green leaves percentage of pear seedlings as affected by different foliar spraying treatments.

Total chlorophyll content of leaves gradually decreased with increasing $\mathrm{NaCl}$ concentration in irrigation water (Table 1). In Pyrus calleryana seedlings, salt stress significantly reduced the chlorophyll contents ${ }^{25}$. Also, ${ }^{24}$ revealed that, reduction of Le-Cont pear seedlings growth parameters as affected by higher salinity was accompanied with reduction of leaf chlorophyll content. When plants are subject to salt stress, chlorophyll metabolism is most easily affected, thus chlorophyll content is often regarded as a hallmark of the damage level ${ }^{25}$. The decrease in chlorophyll concentration in stressed plants could be attributed to the increased activity of the chlorophyll-degrading enzyme, chlorophyllase, or inhibition in chlorophyll biosynthesis ${ }^{26}$.

Highest total chlorophyll contents under severe salinity $(3000 \mathrm{ppm} \mathrm{NaCl}$ ) were achieved by spraying seedlings with ASA or WAEs at 10 and $20 \%$ recording $1.888,1.821,1.839 \mathrm{mg} / \mathrm{g}$ in first season and 1.955 , $1.884,1.903 \mathrm{mg} / \mathrm{g}$ for second season, respectively. On the other hand, lower total chlorophyll contents were observed when seedlings sprayed using tap water and irrigated with 1500 and $3000 \mathrm{ppm} \mathrm{NaCl}$ giving 1.285 , $1.089 \mathrm{mg} / \mathrm{g}$ for first season and 1.316, $1.108 \mathrm{mg} / \mathrm{g}$ in second season, respectively. ASA and $20 \% \mathrm{WAE}$ were superior in this respect giving in average $2.084,2.203 \mathrm{mg} / \mathrm{g}$ in first season and 2.162, $2.288 \mathrm{mg} / \mathrm{g}$ for second season, respectively. Previously, ASA positively affected photosynthetic pigments under both salt and drought stresses ${ }^{26}$ as well as chilling stress ${ }^{27}$. 
Table (1). Total chlorophyll and carotenoid contents $(\mathrm{mg} / \mathrm{g})$ in leaves of pear seedlings grown under saline conditions of irrigation as affected by different foliar spraying treatments.

\begin{tabular}{|c|c|c|c|c|c|c|c|c|c|}
\hline & \multicolumn{4}{|c|}{ Total chlorophyll } & \multicolumn{4}{|c|}{ Carotenoids } \\
\hline & & \multicolumn{8}{|c|}{ First season } \\
\hline \multicolumn{2}{|l|}{ Treatments } & $\mathbf{0}$ & 1500 & 3000 & Mean & $\mathbf{0}$ & 1500 & 3000 & Mean \\
\hline \multicolumn{2}{|l|}{ Control } & 1.571 & 1.285 & 1.089 & 1.315 & 1.285 & 1.067 & 0.957 & 1.103 \\
\hline \multicolumn{2}{|l|}{$\mathbf{S A}$} & 2.330 & 1.998 & 1.547 & 1.958 & 1.898 & 1.668 & 1.221 & 1.596 \\
\hline \multicolumn{2}{|l|}{$\overline{\text { ASA }}$} & 2.296 & 2.067 & 1.888 & 2.084 & 1.864 & 1.661 & 1.574 & 1.700 \\
\hline \multicolumn{2}{|l|}{ 10\% WAE } & 2.094 & 1.936 & 1.821 & 1.950 & 1.536 & 1.419 & 1.559 & 1.505 \\
\hline \multicolumn{2}{|l|}{ 20\% WAE } & 2.640 & 2.129 & 1.839 & 2.203 & 1.937 & 1.710 & 1.520 & 1.722 \\
\hline \multicolumn{2}{|l|}{ Mean } & 2.186 & 1.883 & 1.637 & & 1.704 & 1.505 & 1.366 & \\
\hline \multirow[t]{2}{*}{ L.S.D. $5 \%$} & $\begin{array}{l}\mathrm{NaCl} \\
\text { Treatments } \\
\text { Interaction }\end{array}$ & \multicolumn{4}{|c|}{$\begin{array}{l}0.096 \\
0.124 \\
0.215\end{array}$} & & & & \\
\hline & & \multicolumn{8}{|c|}{ Second season } \\
\hline \multicolumn{2}{|l|}{ Treatments } & $\mathbf{0}$ & 1500 & 3000 & Mean & $\mathbf{0}$ & 1500 & 3000 & Mean \\
\hline \multicolumn{2}{|l|}{ Control } & 1.618 & 1.316 & 1.108 & 1.347 & 1.387 & 1.158 & 1.026 & 1.190 \\
\hline \multicolumn{2}{|l|}{ SA } & 2.423 & 2.071 & 1.593 & 2.029 & 2.072 & 1.808 & 1.328 & 1.736 \\
\hline \multicolumn{2}{|l|}{ ASA } & 2.387 & 2.144 & 1.955 & 2.162 & 2.049 & 1.808 & 1.716 & 1.858 \\
\hline \multicolumn{2}{|l|}{ 10\% WAE } & 2.173 & 2.006 & 1.884 & 2.021 & 1.671 & 1.546 & 1.699 & 1.639 \\
\hline \multicolumn{2}{|l|}{ 20\% WAE } & 2.752 & 2.210 & 1.903 & 2.288 & 2.119 & 1.869 & 1.660 & 1.883 \\
\hline \multicolumn{2}{|l|}{ Mean } & 2.271 & 1.949 & 1.689 & & 1.860 & 1.638 & 1.486 & \\
\hline L.S.D. $5 \%$ & $\begin{array}{l}\mathrm{NaCl} \\
\text { Treatments } \\
\text { Interaction }\end{array}$ & \multicolumn{4}{|c|}{$\begin{array}{l}0.106 \\
0.137 \\
0.237\end{array}$} & \multicolumn{4}{|c|}{$\begin{array}{l}0.103 \\
0.133 \\
0.229\end{array}$} \\
\hline
\end{tabular}

Generally, increasing concentration of $\mathrm{NaCl}$ in irrigation water negatively affected leaves carotenoids content (Table 1). ${ }^{26}$ suggested that, the decrease in carotenoids under stress condition is due to the degradation of B-carotene and formation of zeaxanthins, which are apparently involved in protection against photo inhibition.

All spraying treatments had beneficial effects regarding leaf carotenoids content with relative advantage for both ASA and 20\% WAE treatments recording in average 1.700, $1.722 \mathrm{mg} / \mathrm{g}$ for first season and 1.858 , $1.883 \mathrm{mg} / \mathrm{g}$ in second season, respectively. However, lower total carotenoid contents were observed when seedlings sprayed using tap water and irrigated with 1500 and $3000 \mathrm{ppm} \mathrm{NaCl}$ giving 1.067, $0.957 \mathrm{mg} / \mathrm{g}$ for first season and $1.158,1.026 \mathrm{mg} / \mathrm{g}$ in second season, respectively.

\section{Root system growth}

Concerning number of roots, WAE at $10 \%$ was the most effective giving the highest means of 10.3 and 10.4 in both seasons, respectively (Table 2). 
Table (2). Root system growth of pear seedlings grown under saline conditions of irrigation as affected by different foliar spraying treatments.

\begin{tabular}{|c|c|c|c|c|c|c|c|c|c|}
\hline & \multicolumn{4}{|c|}{ Number of roots } & \multicolumn{4}{|c|}{ Average length of roots $(\mathrm{cm})$} \\
\hline & & \multicolumn{8}{|c|}{ First season } \\
\hline \multicolumn{2}{|l|}{ Treatments } & $\mathbf{0}$ & 1500 & 3000 & Mean & $\mathbf{0}$ & 1500 & 3000 & Mean \\
\hline \multicolumn{2}{|l|}{ Control } & 9.0 & 8.0 & 10.0 & 9.0 & 40.0 & 37.0 & 33.0 & 36.7 \\
\hline \multicolumn{2}{|l|}{ SA } & 8.0 & 9.0 & 11.0 & 9.3 & 37.0 & 42.0 & 41.0 & 40.0 \\
\hline \multicolumn{2}{|l|}{ ASA } & 8.0 & 9.0 & 9.0 & 8.7 & 38.0 & 41.0 & 41.0 & 40.0 \\
\hline \multicolumn{2}{|l|}{ 10\% WAE } & 10.0 & 10.0 & 11.0 & 10.3 & 39.0 & 40.0 & 39.5 & 39.5 \\
\hline \multicolumn{2}{|l|}{ 20\% WAE } & 8.0 & 9.0 & 9.0 & 8.7 & 37.0 & 43.0 & 43.0 & 41.0 \\
\hline \multicolumn{2}{|l|}{ Mean } & 8.6 & 9.0 & $\mathbf{1 0 . 0}$ & & 38.2 & 40.6 & 39.5 & \\
\hline \multirow[t]{2}{*}{ L.S.D. $5 \%$} & $\begin{array}{l}\mathrm{NaCl} \\
\text { Treatments } \\
\text { Interaction }\end{array}$ & \multicolumn{4}{|c|}{$\begin{array}{l}1.084 \\
1.399 \\
2.423\end{array}$} & \multicolumn{4}{|c|}{$\begin{array}{l}0.876 \\
1.130 \\
1.958\end{array}$} \\
\hline & & \multicolumn{8}{|c|}{ Second season } \\
\hline \multicolumn{2}{|l|}{ Treatments } & $\mathbf{0}$ & 1500 & 3000 & Mean & $\mathbf{0}$ & 1500 & 3000 & Mean \\
\hline Control & & 8.7 & 8.3 & 9.0 & 8.7 & 40.4 & 37.8 & 33.9 & 37.4 \\
\hline \multicolumn{2}{|l|}{ SA } & 8.7 & 9.3 & 9.7 & 9.2 & 37.5 & 42.8 & 41.8 & 40.7 \\
\hline \multicolumn{2}{|l|}{ ASA } & 8.3 & 10.0 & 9.0 & 9.1 & 38.6 & 41.8 & 41.8 & 40.7 \\
\hline \multicolumn{2}{|l|}{ 10\% WAE } & 10.0 & 10.3 & 11.0 & 10.4 & 39.4 & 40.9 & 40.2 & 40.2 \\
\hline \multicolumn{2}{|l|}{ 20\% WAE } & 8.3 & 8.3 & 9.3 & 8.6 & 37.3 & 43.9 & 43.8 & 41.7 \\
\hline \multicolumn{2}{|l|}{ Mean } & 8.8 & 9.2 & 9.6 & & 38.6 & 41.4 & 40.3 & \\
\hline L.S.D. $5 \%$ & $\begin{array}{l}\mathrm{NaCl} \\
\text { Treatments } \\
\text { Interaction }\end{array}$ & & & & & & & & \\
\hline
\end{tabular}

Root length gradually decreased as salinity of irrigation water increased in control seedlings (Table 2). ${ }^{24}$ observed that, salinity significantly minimized Le-Cont pear seedlings root system growth in terms of root length.

Regarding the effect of spraying treatments, foliar applications during both seasons showed significant positive effects in terms of root length as compared to control which gave the lowest values recording in average $36.7,37.4 \mathrm{~cm}$ for first and second seasons, respectively.

\section{Proline content}

Generally, proline contents of pear seedlings increased under salt stress conditions (Table 3). In parallel, proline content in pear seedlings gradually increased by increasing irrigation water salinity as reported by $^{23,24}$. Proline plays a role in the protection against abiotic stress by assisting osmotic regulation, removing hydroxyl free radicals, avoiding the destruction of enzymes and protection of macromolecules as well as DNA structures $^{27,28}$. 
Table (3). Proline content $(\mathrm{mg} / \mathbf{1 0 0 g})$ of pear seedlings grown under saline conditions of irrigation as affected by different foliar spraying treatments.

\begin{tabular}{|c|c|c|c|c|c|c|c|c|c|}
\hline & \multicolumn{4}{|c|}{ Leaves } & \multicolumn{4}{|c|}{ Roots } \\
\hline & & \multicolumn{8}{|c|}{ First season } \\
\hline \multicolumn{2}{|r|}{$\mathrm{NaCl}$ (ppm) } & $\mathbf{0}$ & 1500 & 3000 & Mean & $\mathbf{0}$ & 1500 & 3000 & Mean \\
\hline \multicolumn{2}{|l|}{ Control } & 3.660 & 4.664 & 2.152 & 3.492 & 2.946 & 2.830 & 2.284 & 2.687 \\
\hline \multicolumn{2}{|l|}{ SA } & 3.603 & 4.389 & 4.203 & 4.065 & 1.930 & 2.389 & 2.435 & 2.251 \\
\hline \multicolumn{2}{|l|}{$\overline{\text { ASA }}$} & 3.847 & 4.340 & 4.529 & 4.239 & 2.225 & 2.398 & 2.706 & 2.443 \\
\hline \multicolumn{2}{|l|}{ 10\% WAE } & 2.837 & 4.997 & 5.745 & 4.526 & 1.440 & 2.511 & 2.777 & 2.243 \\
\hline \multicolumn{2}{|l|}{ 20\% WAE } & 4.703 & 5.095 & 4.729 & 4.842 & 2.252 & 3.600 & 3.745 & 3.199 \\
\hline \multicolumn{2}{|l|}{ Mean } & 3.730 & 4.697 & 4.272 & & 2.159 & 2.746 & 2.789 & \\
\hline \multirow[t]{2}{*}{ L.S.D. $5 \%$} & $\begin{array}{l}\mathrm{NaCl} \\
\text { Treatments } \\
\text { Interaction }\end{array}$ & \multicolumn{4}{|c|}{$\begin{array}{l}0.141 \\
0.244\end{array}$} & & $\begin{array}{l}0 . \\
0 . \\
0 .\end{array}$ & & \\
\hline & & \multicolumn{8}{|c|}{ Second season } \\
\hline \multicolumn{2}{|l|}{ Treatments } & $\mathbf{0}$ & 1500 & 3000 & Mean & $\mathbf{0}$ & 1500 & 3000 & Mean \\
\hline \multicolumn{2}{|l|}{ Control } & 3.761 & 4.805 & 2.192 & 3.586 & 3.214 & 3.098 & 2.486 & 2.933 \\
\hline \multicolumn{2}{|l|}{$\mathbf{S A}$} & 3.701 & 4.519 & 4.325 & 4.182 & 2.108 & 2.602 & 2.663 & 2.458 \\
\hline \multicolumn{2}{|l|}{ ASA } & 3.955 & 4.468 & 4.664 & 4.362 & 2.447 & 2.619 & 2.961 & 2.676 \\
\hline \multicolumn{2}{|l|}{ 10\% WAE } & 2.905 & 5.151 & 5.929 & 4.662 & 1.565 & 2.747 & 3.039 & 2.450 \\
\hline \multicolumn{2}{|l|}{ 20\% WAE } & 4.845 & 5.253 & 4.872 & 4.990 & 2.466 & 3.948 & 4.108 & $\mathbf{3 . 5 0 7}$ \\
\hline \multicolumn{2}{|l|}{ Mean } & 3.833 & 4.839 & 4.396 & & 2.360 & 3.003 & 3.051 & \\
\hline L.S.D. $5 \%$ & $\begin{array}{l}\mathrm{NaCl} \\
\text { Treatments } \\
\text { Interaction }\end{array}$ & \multicolumn{4}{|c|}{0.104} & & $\begin{array}{l}0 . \\
0 . \\
0 .\end{array}$ & & \\
\hline
\end{tabular}

All foliar applications enhanced proline content of leaves and roots under severe salinity conditions $(3000 \mathrm{ppm} \mathrm{NaCl})$ of irrigation water compared with control. However, foliar application of $20 \%$ WAE recorded the highest averages in both leaves $(4.842,4.990 \mathrm{mg} / 100 \mathrm{~g}$ in first and second seasons, respectively), and roots $(3.199,3.507 \mathrm{mg} / 100 \mathrm{~g}$ in first and second seasons, respectively).

The exogenous application of ASA significantly increased the accumulation of proline under chilling ${ }^{27}$ and water stress conditions ${ }^{28}$. Also, treatment with $0.5 \mathrm{mM} \mathrm{SA}$ mitigates heat stress by increasing proline production by increasing $\gamma$-glutamyl kinase and decreasing proline oxidase activity, resulting in the promotion of osmotic potential necessary for maintaining crucial physiological processes ${ }^{29}$.

\section{Total phenols content}

As for the effect of spraying treatments, all foliar applications enhanced total phenols of both leaves and roots under salinity conditions of irrigation water compared with control (Table 4). WAEs revealed higher seedlings total phenol contents in average during both seasons. 
Table (4). Total phenols content (\%) of pear seedlings grown under saline conditions of irrigation as affected by different foliar spraying treatments.

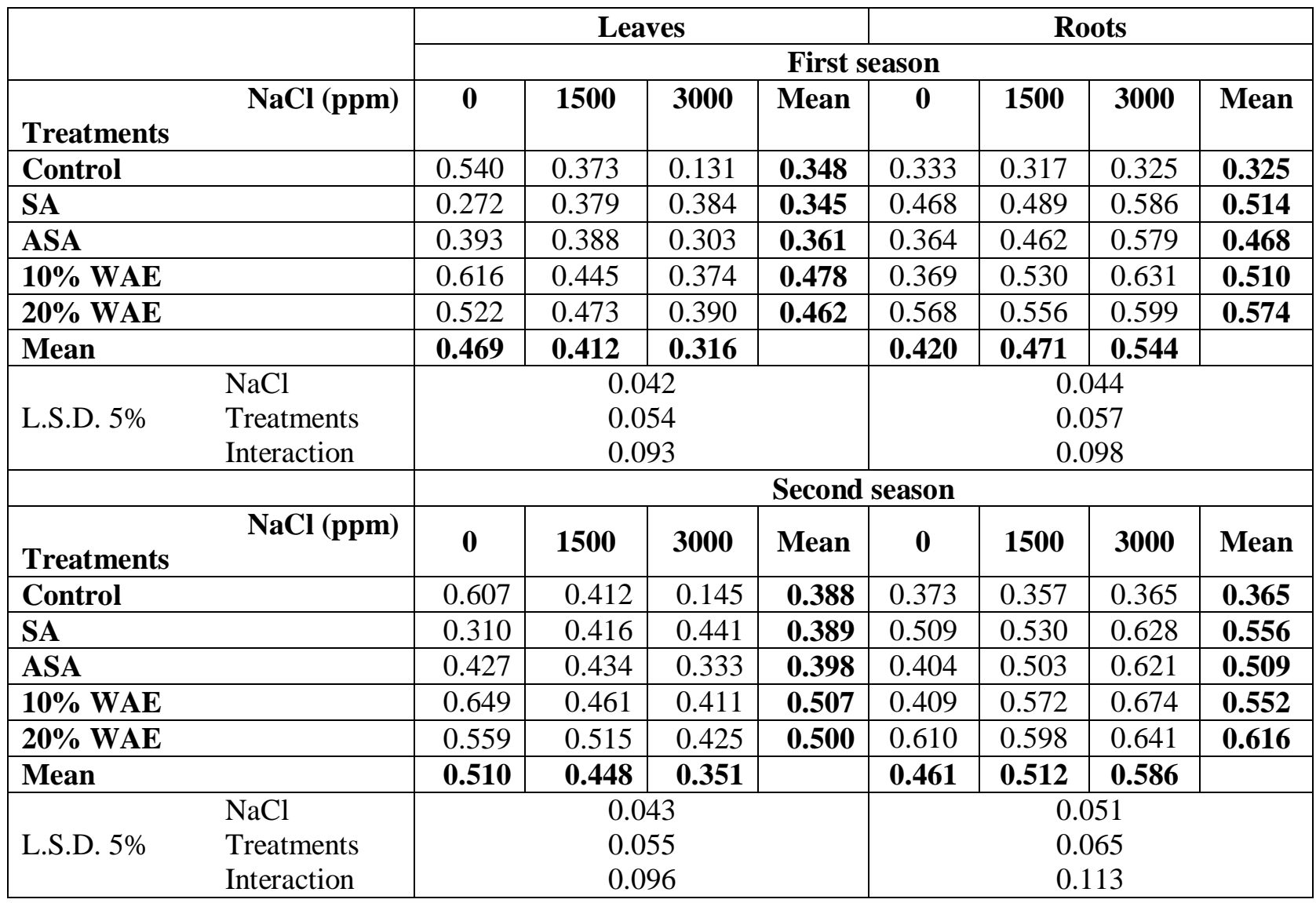

\section{Antioxidant activity}

Regarding antioxidant activity of pear seedlings extract (Table 5), foliar applications during both seasons showed significant positive effects for both leaves and roots as compared to control which gave the lowest values recording in average 83.37, 83.96\% in the first season and 83.95, 84.79\% in the second season, respectively. Antioxidant system stimulation by some applications is reported to alleviate the adverse conditions of salinity ${ }^{30,31}$. There appears to be a significant correlation between the content of total phenolics and antioxidant activity ${ }^{32} .{ }^{33}$ showed that, the phenolic compounds are the major contributors to the antioxidative activities. They form complexes with the metals, which catalyse oxygenation reactions and inhibit activity of oxidizing enzymes ${ }^{34}$. 
Table (5). Antioxidant activity (\%) of pear seedlings grown under saline conditions of irrigation as affected by different foliar spraying treatments.

\begin{tabular}{|c|c|c|c|c|c|c|c|c|c|}
\hline & \multicolumn{4}{|c|}{ Leaves } & \multicolumn{4}{|c|}{ Roots } \\
\hline & & \multicolumn{8}{|c|}{ First season } \\
\hline \multicolumn{2}{|l|}{ Treatments } & $\mathbf{0}$ & 1500 & 3000 & Mean & 0 & 1500 & 3000 & Mean \\
\hline \multicolumn{2}{|l|}{ Control } & 84.41 & 85.67 & 80.03 & 83.37 & 81.61 & 83.82 & 86.46 & 83.96 \\
\hline \multicolumn{2}{|l|}{ SA } & 95.57 & 96.32 & 84.92 & 92.27 & 84.31 & 86.66 & 95.03 & 88.67 \\
\hline \multicolumn{2}{|l|}{ ASA } & 91.54 & 95.01 & 83.85 & 90.13 & 95.28 & 94.97 & 95.49 & 95.25 \\
\hline \multicolumn{2}{|l|}{ 10\% WAE } & 87.14 & 91.65 & 81.69 & 86.83 & 93.06 & 92.70 & 92.16 & 92.64 \\
\hline \multicolumn{2}{|l|}{ 20\% WAE } & 87.47 & 95.54 & 84.33 & 89.11 & 94.88 & 93.54 & 92.95 & 93.79 \\
\hline \multicolumn{2}{|l|}{ Mean } & 89.23 & 92.84 & 82.96 & & 89.83 & 90.34 & 92.42 & \\
\hline \multirow[t]{2}{*}{ L.S.D. $5 \%$} & $\begin{array}{l}\mathrm{NaCl} \\
\text { Treatments } \\
\text { Interaction }\end{array}$ & \multicolumn{4}{|c|}{$\begin{array}{l}1.277 \\
2.212\end{array}$} & & $\begin{array}{l}0 . \\
0 . \\
1 .\end{array}$ & & \\
\hline & & \multicolumn{8}{|c|}{ Second season } \\
\hline \multicolumn{2}{|l|}{ Treatments } & $\mathbf{0}$ & 1500 & 3000 & Mean & $\mathbf{0}$ & 1500 & 3000 & Mean \\
\hline \multicolumn{2}{|l|}{ Control } & 84.89 & 86.50 & 80.47 & 83.95 & 82.01 & 84.76 & 87.59 & 84.79 \\
\hline \multicolumn{2}{|l|}{$\mathbf{S A}$} & 95.83 & 97.25 & 85.08 & 92.72 & 84.92 & 87.45 & 95.92 & 89.43 \\
\hline \multicolumn{2}{|l|}{ ASA } & 92.08 & 95.93 & 83.98 & 90.66 & 96.08 & 95.85 & 96.38 & 96.10 \\
\hline \multicolumn{2}{|l|}{ 10\% WAE } & 87.48 & 92.31 & 81.97 & 87.25 & 93.59 & 93.71 & 93.02 & 93.44 \\
\hline \multicolumn{2}{|l|}{ 20\% WAE } & 87.96 & 96.02 & 84.63 & 89.54 & 95.43 & 94.55 & 93.85 & 94.61 \\
\hline \multicolumn{2}{|l|}{ Mean } & 89.65 & 93.60 & 83.23 & & 90.41 & 91.26 & 93.35 & \\
\hline L.S.D. $5 \%$ & $\begin{array}{l}\mathrm{NaCl} \\
\text { Treatments } \\
\text { Interaction }\end{array}$ & \multicolumn{4}{|c|}{$\begin{array}{l}1.301 \\
1.680 \\
2.910\end{array}$} & \multicolumn{4}{|c|}{$\begin{array}{l}1.296 \\
1.674 \\
2.899\end{array}$} \\
\hline
\end{tabular}

\section{Expression of PbHB1-22 gene}

The results confirmed that PbHB1-22 displays stress-inducible expression patterns (Figure 2). These results are in agreement with ${ }^{20}$ who revealed that, the expression level of PbHB22 gene was up-regulated as response to biotic and abiotic stresses in pear.

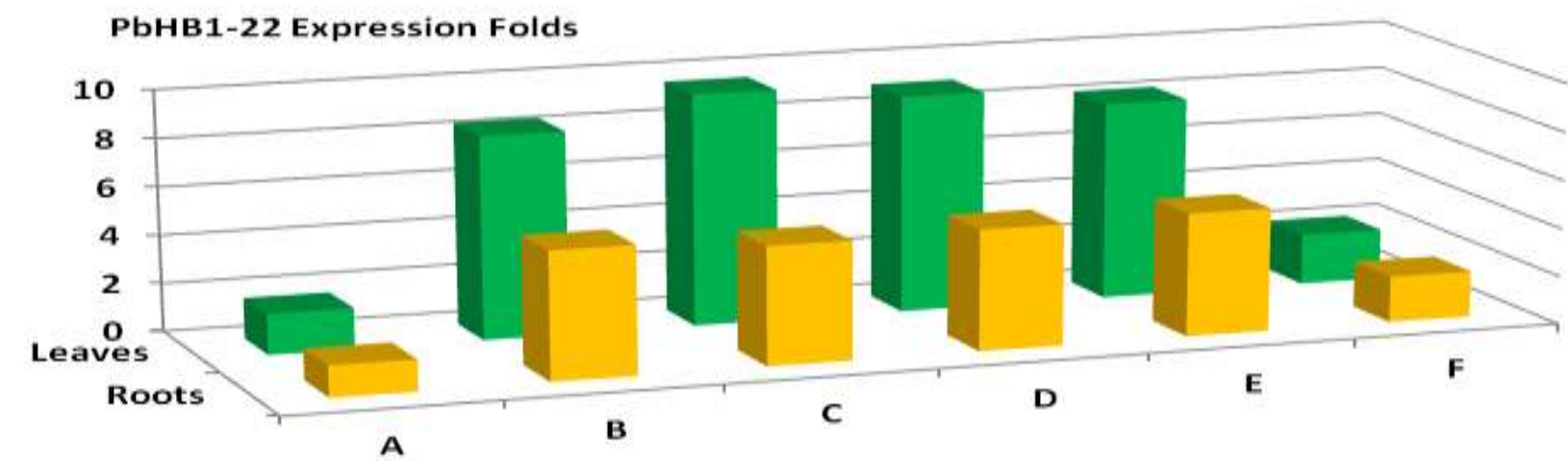

\begin{tabular}{|l|c|c|c|c|c|c|}
\cline { 2 - 7 } \multicolumn{1}{c|}{} & A & B & C & D & E & F \\
\hline Roots & 1.3 & 5.3 & 4.9 & 5 & 5.1 & 1.9 \\
\hline Leaves & 1.7 & 8.4 & 9.6 & 9 & 8.2 & 2.1 \\
\hline
\end{tabular}

Figure (2). Change in regulation of PbHB1-22 gene in pear leaves and roots under severe salinity conditions (3000 $\mathrm{ppm} \mathrm{NaCl})$ as affected by different foliar applications comparing to control. A: tap water irrigated control, B-F: stressed seedlings; B: tap water, C: $0.5 \mathrm{mM}$ salicylic acid, D: $0.5 \mathrm{mM}$ acetylsalicylic acid, E: $10 \%$ white willow aqueous extract, F: $20 \%$ white willow aqueous extract. 
Remarkable reduction in PbHB1-22 expression folds under salt stress was observed when pear seedlings were sprayed using $20 \%$ WAE to reach almost normal levels, while slight upregulation in leaves occurred as a response to SA and ASA treatments. Obtained results are partially in agreement with ${ }^{27}$ who revealed that, ASA significantly upregulated the cold-responsive genes CBF3 and COR47.

Plants launch complex cellular, physiological, and molecular responses during their developmental processes. These responses are usually regulated by transcription factors. The Homeodomain-leucine zipper (HD-Zip) transcription factors are unique to the plant kingdom. Studies show that HD-Zip family genes participate in different biological processes of growth and development of plants as well as adaptation response to environmental stress. Members of HD-Zip subfamilies I and II act as the integrators of development and environmental cues and endogenous hormone signal pathway to regulate targeted gene expression and plant adaptation response ${ }^{35}$. Previous studies have shown that HD-Zip genes were involved in regulating adaptive response of plants to various stress conditions, such as drought ${ }^{36}$, salt ${ }^{35}$ and bacteria ${ }^{37}$. The expression patterns of PbHB genes revealed that, pear HD-Zip genes were widely involved in responding to drought- and saltinduced stress as well as pathogen infection ${ }^{20}$. The HD-Zip I Arabidopsis genes ATHB7 and ATHB12 act as negative regulators of growth and development by reducing plant growth under water-deficit conditions ${ }^{38-40}$. HAHB10, a member of HD-Zip II subfamily in sunflower, was involved in promoting the accumulation of salicylic acid (SA) upon biotic stresses ${ }^{37}$.

\section{In-vitro screening of antibacterial activity against Erwinia amylovora}

Effect of salicylic acid (SA), acetylsalicylic acid (ASA) and white willow extracts (WAEs) as antibacterial agents on in vitro growth of Erwinia amylovora was studied. Only both WAE concentrations (10 and $20 \%$ ) were effective against E. amylovora (Figure 3), on the other hand, SA, ASA and control had no effect against the bacteria. The inhibition zone was significantly increased by increasing WAE concentration (10 and 20\%) recording 6.7 and $12.3 \mathrm{~mm}$, respectively.

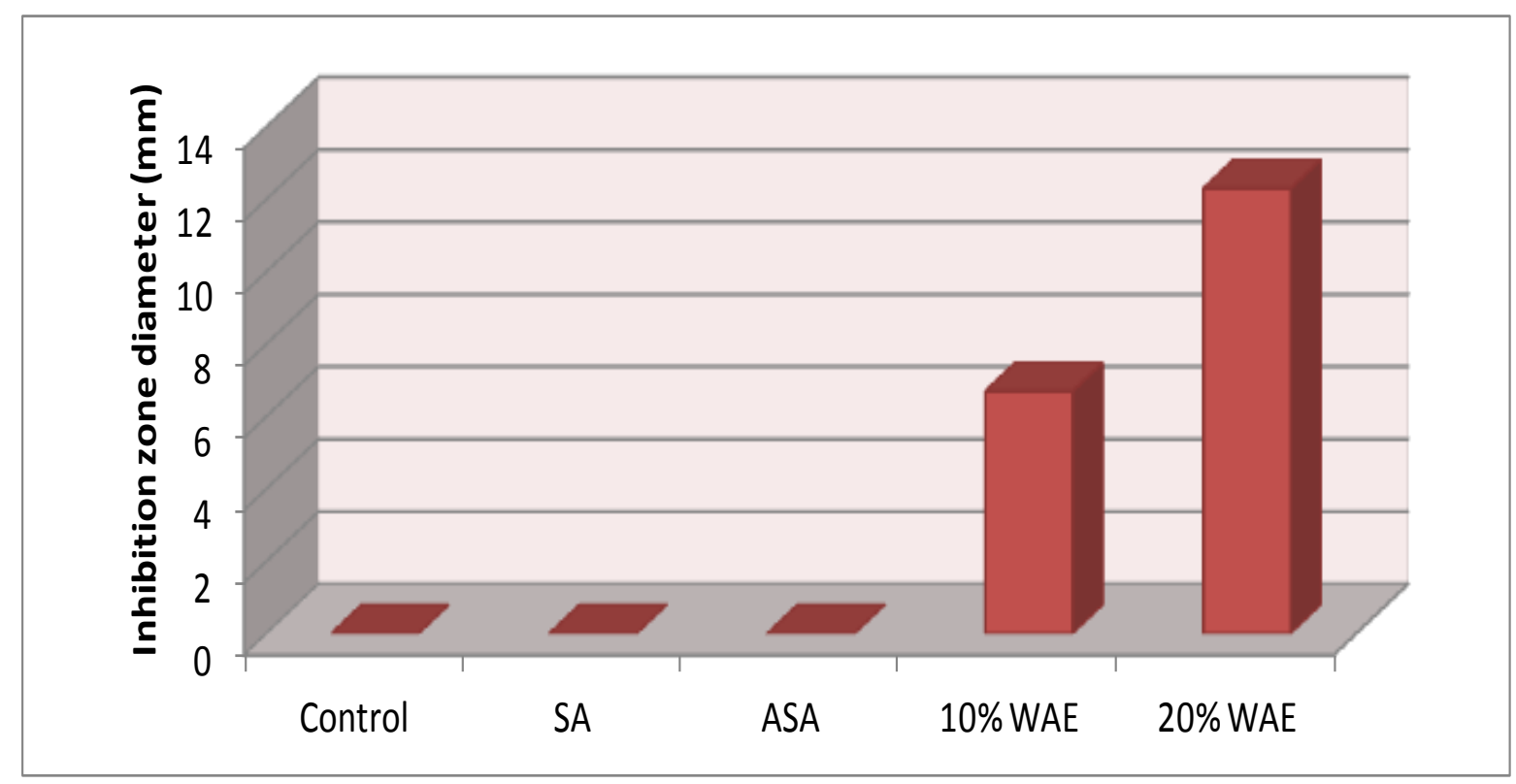

Figure (3). Effect of salicylic acid (SA), acetylsalicylic acid (ASA) and white willow extracts (WAEs) on in vitro growth of Erwinia amylovora (L.S.D. at 5\%= 0.4175).

Salix alba leaves extract at $25 \%$ inhibited the in vitro growth of Erwinia carotovora subsp. carotovora $^{21}$. In addition, the crude Salix alba leaves extract was found to have minimum inhibitory concentration (the lowest extract concentration that showed significant inhibition of growth compared to the controls) of $800-1600 \mu \mathrm{g} / \mathrm{ml}$ against different Candida yeast species, effective inhibition found to increase in concentration dependent manner ${ }^{8}$. 
Salicylic acid inhibited in vitro growth of Erwinia carotovora ${ }^{41} .{ }^{42}$ revealed that, only at higher SA concentrations (over $5 \mathrm{mM}$ ) could a clear decrease in the in vitro growth rate of Erwinia carotovora subsp. carotovora be observed. The most likely explanation for SA-induced resistance to E. $c$. subsp. carotovora at lower concentrations (up to $1 \mathrm{mM}$ ), where higher SA concentrations negatively affected plant growth, is the elicitation of plant defense. The molecular mechanism of the SA-induced resistance to E. $c$. subsp. carotovora appears to involve inhibition of cell wall-degrading enzymes secreted by the pathogen.

The application of exogenous acetylsalicylic acid (ASA) alleviated the adverse effects of various abiotic stresses; salt, water ${ }^{26}$, chilling ${ }^{27}$ and heat ${ }^{43}$. Pretreatment of ASA appeared to induce pre-adaptive responses to salt and water stresses leading to promote protective reactions ${ }^{26}$. The exogenous application of ASA most likely significantly increases the activity of the antioxidant system, directly impacting the intensity of photosynthesis ${ }^{27}$. Also, ${ }^{44}$ reported that, SA-induced salt tolerance due to the improvement in chlorophyll content and the flow of antioxidant enzyme activity that consequently alleviates oxidative stress and enhances the photosynthetic process.

SA or ASA at $0.5 \mathrm{mM}$ were effective against heat, cold and drought stresses, while concentrations over $1 \mathrm{mM}$ ASA or SA appeared to have adverse effects ${ }^{45}$. They suggested that, SA and ASA trigger the expression of the potential to tolerate stress by inducing systemic acquired resistance (SAR) rather than having any direct effect as a protectant.

Acetylsalicylic acid (ASA) or aspirin, a synthetic derivative of salicylic acid (SA), undergoes spontaneous hydrolysis to SA in aqueous solution. Salicylic acid is an endogenous growth regulator of phenolic nature, which participates in the regulation of physiological processes in plants. SA could be included in the category of phytohormones. Exogenous application of SA may influence a range of diverse processes in plants, including seed germination, stomatal closure, ion uptake and transport, membrane permeability, photosynthetic and growth rate. SA is also known as an important signal molecule for modulating plant responses to environmental stresses. It is now clear that SA provides protection against a number of biotic and abiotic stresses $^{26}$. SA is involved in the adjustment of vital plant physiochemical activities, such as the light and dark reactions, carbon-nitrogen metabolism, proline metabolism, and ROS scavenger systems, and therefore offers protection against abiotic stresses in plants ${ }^{27}$.

The beneficial effects of plant's natural extracts on growth, yield and some chemical constituents under abiotic stress conditions has been reported with different plant extracts ${ }^{46-50}$. Natural resources have provided an unparalleled source of chemical scaffolds with diverse biological activities. Plants containing phytochemicals not only have effect on some particular diseases, but because of their antioxidant or hormone like actions, they also give more beneficial effects. Therefore, the benefits ascribed to Salix cannot be unambiguously attributed to a single class of compounds, but rather to the multiple contribution of its different bioactive compounds. The biological properties of Salix may attributed to its phytochemical composition rich in phenolics, with positive contribution of flavonoids, as antioxidans as well as salicylates.

\section{References}

1. Jackson, J.E. Biology of Apples and Pears, Cambridge University Press, United Kingdom, 2003, 488.

2. Okubo, M.; Furukawa, Y. and Sakuratani, T. Growth, flowering and leaf properties of pear cultivars grafted on two Asian pear rootstock seedlings under $\mathrm{NaCl}$ irrigation. Scientia Horticulturae, 2000, 85: 91-101.

3. Tyagi, N.K. Optimal water management strategies for salinity control. Irrigation and Drainage, 1986, 112: 81-97.

4. Saad El-Dein, A.A. and Galal, M.E. Prediction of reclamation processes in some saline soils of Egypt. Egypt. J. Soil Sci., 2017, 57: 293-301.

5. Mohamed, E.S.; Morgun, E.G. and Goma Bothina S.M. Assessment of soil salinity in the Eastern Nile Delta (Egypt) using geoinformation techniques. Moscow University Soil Science Bulletin, 2011, 66: 11-14.

6. Cramer, G.R.; Abdel-Basset, R. and Seemann, J.R. Salinity calcium interaction on root growth and osmotic adjustment of two corn cultivars differing in salt tolerance. J. Plant. Nutr., 1990, 13: 14531462. 
7. Ashraf, M.Y.; Sarwar, G.; Ashraf, M.; Afaf, R. and Sattar, A. Salinity induced changes in a-amylase activity during germination and early cotton seedling growth. Biologia Plantarum, 2002, 45: 589-591.

8. Zarger, M.S.S.; Khatoon, F. and Akhtar, N. Phytochemical investigation and growth inhibiting effects of Salix alba leaves against some pathogenic fungal isolates. World Journal of Pharmacy and Pharmacology Sciences, 2014, 3: 1320-1330.

9. Norn, S.; Permin, H.; Kruse, P.R. and Kruse, E. From willow bark to acetylsalicylic acid. Dan Medicinhist Arbog., 2009, 37: 79-98.

10. Du, Q.; Jerz, G.; Ha, Y.; Li, L. Xu, Y.; Zhang, Q.; Zheng, Q.; Winterhalter, P. and Ito, Y. Semiindustrial isolation of salicin and amygdalin from plant extracts using slow rotary counter-current. Chromatography, 2005, 13: 43-46.

11. Dempsey, D.M.A. and Klessig, D.F. How does the multifaceted plant hormone salicylic acid combat disease in plants and are similar mechanisms utilized in humans?. BMC Biol., 2017, 15: 1-11.

12. Vlot, A.C.; Dempsey, D.A. and Klessig, D.F. Salicylic acid, a multifaceted hormone to combat disease. Annu. Rev. Phytopathol., 2009, 47:177-206.

13. Kahn, M.I.R.; Fatma, M.; Per, T.S.; Anjum, N.A. and Kahn, N.A. Salicylic acid-induced abiotic stress tolerance and underlying mechanisms in plants. Front Plant Sci., 2015, 6: 462.

14. Miura, K. and Tada, Y. Regulation of water, salinity, and cold stress responses by salicylic acid. Front Plant Sci., 2014, 5: 4.

15. Holm, G. Chlorophyll mutations in barley. Acta Agr. Scand., 1954, 4: 457-471.

16. Wettstein, D. Chlorophyll-letale und der submikroskopische Formwechsel der Plastiden. Exp. Cell Res., 1957, 12: 427-506.

17. Handa, S.; Bressan, R.A.; Handa, A.K.; Carpita, N.C. and Hasegawa, P.M. Solutes contributing to osmotic adjustment in cultured plant cells adapted to water stress. Plant Physiol., 1983, 73: 834-843.

18. Swain, T. and Hillis, W.E. The phenolic constituents of Prunus domestica. I. The quantitative analysis of phenolic constituents. J. Sci. Food Agric., 1959, 10: 63-68.

19. Blois, M.S. Antioxidant determinations by the use of a stable free radical. Nature, 2002, 26: 1199-1200.

20. Wang, H.; Lin, J.; Li, X.G. and Chang, Y. Genome-wide identification of pear HD-Zip gene family and expression patterns under stress induced by drought, salinity, and pathogen. Acta Physiol. Plant., 2015, 37: 189.

21. Bhat, K.A.; Viswanath, H.S.; Bhat, N.A. and Wani, T.A. Bioactivity of various ethanolic plant extracts against Pectobacterium carotovorum subsp. carotovorum causing soft rot of potato tubers. Indian Phytopathology, 2017, 70: 463-470.

22. Snedecor, G.W. and Cochran, W.G. Statistical Methods. $8^{\text {th }}$ Ed. The Iowa State Univ. press. Ames., Iowa, U.S.A., 1989.

23. Osman, E.A.M.; Abd El-Latif, K.M.; Hussien, S.M. and Sherif, A.E.A. Assessing the effect of irrigation with different levels of saline magnetic water on growth parameters and mineral contents of pear seedlings. Global Journal of Scientific Researches, 2014, 2: 128-136.

24. Eissa, F.M.; Fathi, M.A. and El-Shall, S.A. The role of humic acid and rootstock in enhancing salt tolerance of "Le-Cont" pear seedlings. J. Agric. Sci. Mansoura Univ., 2007, 32: 3651-3666.

25. Li, X.; Dong, W.; Lin, J.; Wang, Z.; Yang, Q.; Chang, Y. and Zhang, Z. Structural, physiological and biochemical responses of Pyrus calleryana offspring to salt stress. Eur. J. Hortic. Sci., 2015, 80: 306315.

26. Daneshmand, F.; Arvin, M.J. and Kalantari, K.M. Effect of acetylsalicylic acid (Aspirin) on salt and osmotic stress tolerance in Solanum bulbocastanum in vitro: enzymatic antioxidants. AmericanEurasian J. Agric. \& Environ. Sci., 2009, 6: 92-99.

27. Soliman, M.H.; Alayafi, A.A.M.; El Kelish, A.A. and Abu-Elsaoud, A.M. Acetylsalicylic acid enhance tolerance of Phaseolus vulgaris L. to chilling stress, improving photosynthesis, antioxidants and expression of cold stress responsive genes. Bot. Stud., 2018, 59: 6.

28. Kabiri, R. and Naghizadeh, M. Exogenous acetylsalicylic acid stimulates' physiological changes to improve growth, yield and yield components of barley under water stress condition. Journal of Plant Physiology and Breeding, 2015, 5: 35-45.

29. Khan, M.I.R.; Iqbal, N.; Masood, A.; Per, T.S. and Khan, N.A. Salicylic acid alleviates adverse effects of heat stress on photosynthesis through changes in proline production and ethylene formation. Plant Signaling \& Behavior, 2013, 8: e26374. 
30. Rady, M.M.; Bhavya Varma, C. and Howladar, S.M. Common bean (Phaseolus vulgaris L.) seedlings overcome $\mathrm{NaCl}$ stress as a result of presoaking in Moringa oleifera leaf extract. Sci. Hortic., 2013, 162: 63-70.

31. Korkmaz, A.; Sirikci, R.; Kocacinar, F.; Deger, O. and Demirkirian, A.R. Alleviation of salt-induced adverse effects in pepper seedlings by seed application of glycinebetaine. Sci. Hortic., 2012, 148: 197 205.

32. Król, A.; Amarowicz, R. and Weidner, S. Changes in the composition of phenolic compounds and antioxidant properties of grapevine roots and leaves (Vitis vinifera L.) under continuous of long-term drought stress. Acta Physiol. Plant., 2014, 36: 1491-1499.

33. Zainol, M.K.; Abd-Hamid, A.; Yusof, S. and Muse, R. Antioxidative activity and total phenolic compounds of leaf, root and petiole of four accessions of Centella asiatica (L.) Urban. Food Chem., 2003, 81:575-581.

34. Elavarthi, S. and Martin, B. Spectrophotometric assays for antioxidant enzymes in plants. Methods Mol. Biol., 2010, 639: 273-281.

35. Harris, J.C.; Hrmova, M.; Lopato, S. and Langridge, P. Modulation of plant growth by HD-Zip class I and II transcription factors in response to environmental stimuli. New Phytologist, 2011, 190: 823-837.

36. Zhang, S.; Haider, I.; Kohlen, W.; Jiang, L.; Bouwmeester, H.; Meijer, A.H.; Schluepmann, H.; Liu, C.M. and Ouwerkerk, P.B. Function of the HD-Zip I gene Oshox22 in ABA-mediated drought and salt tolerances in rice. Plant Mol. Biol., 2012, 80: 571-585.

37. Dezar, C.A.; Giacomelli, J.I.; Manavella, P.A.; Re', D.A.; Alves-Ferreira, M.; Baldwin, I.T.; Bonaventure, G. and Chan, R.L. HAHB10, a sunflower HD-Zip II transcription factor, participates in the induction of flowering and in the control of phytohormone-mediated responses to biotic stress. J. Exp. Bot., 2011, 62: 1061-1076.

38. Son, O.; Hur, Y.S.; Kim, Y.K.; Lee, H.J.; Kim, S.; Kim, M.R.; Nam, K.H.; Lee, M.S.; Kim, B.Y.; Park, J.; Lee, S.C.; Hanada, A.; Yamaguchi, S.; Lee, I.J.; Kim, S.K.; Yun, D.J.; Soderman, E. and Cheon, C.I. ATHB12, an ABA-inducible homeodomain-leucine zipper (HD-Zip) protein of Arabidopsis, negatively regulates the growth of the inflorescence stem by decreasing the expression of a gibberellin 20-oxidase gene. Plant Cell Physiol., 2010, 51: 1537-1547.

39. Olsson, A.; Engstrom, P. and Soderman, E. The homeobox genes ATHB12 and ATHB7 encode potential regulators of growth in response to water deficit in Arabidopsis. Plant Mol. Biol., 2004, 55: 663-677.

40. Hjellstrom, M.; Olsson, A.S.B.; Engstrom, P. and Soderman, E.M. Constitutive expression of the water deficit-inducible homeobox gene ATHB7 in transgenic Arabidopsis causes a suppression of stem elongation growth. Plant Cell Environ., 2003, 26: 1127-1136.

41. Lyon, G.D. and McGill, E.M. Inhibition of growth of Erwinia carotovora in vitro by phenolics. Potato Research, 1988, 31: 461-467.

42. Palva, T.K.; Hurtig, M.; Saindrenan, P. and Palva, E.T. Salicylic acid induced resistance to Erwinia carotovora subsp. carotovora in tobacco. Molecular Plant-Microbe Interactions, 1994, 7: 356-363.

43. Lopez-Delgado, H.; Dat, J.F.; Foyer, C.H. and Scott, I.M. Induction of thermotolerance in potato microplants by acetylsalicylic acid and $\mathrm{H}_{2} \mathrm{O}_{2}$. J. Exp. Bot., 1998, 49: 713-720.

44. Li, T.; Hu, Y.; Du, X.; Tang, H; Shen, C. and Wu, J. Salicylic acid alleviates the adverse effects of salt stress in Torreya grandis cv. Merrillii seedlings by activating photosynthesis and enhancing antioxidant systems. PLoS ONE, 2014, 9(10): e109492.

45. Senaratna, T.; Touchell, D.; Bunn, E. and Dixon, K. Acetyl salicylic acid (Aspirin) and salicylic acid induce multiple stress tolerance in bean and tomato plants. Plant Growth Regulation, 2000, 30: 157161.

46. Mahmoud, R.A. and Dahab, A.A. Response of apple seedlings grown under saline conditions to natural plant extracts. Bioscience Research, 2018, 15: 589-601.

47. Hanafy, R.S. Using Moringa oleifera leaf extract as a bio-fertilizer for drought stress mitigation of Glycine max L. plants. Egypt. J. Bot., 2017, 57: 281-292.

48. Sofy, M.R.; Sharaf, A.M.A.; Osman, M.S. and Sofy, A.R. Physiological changes, antioxidant activity, lipid peroxidation and yield characters of salt stressed barely plant in response to treatment with Sargassum extract. Int. J. Adv. Res. Biol. Sci., 2017, 4: 90-109.

49. Semida, W.M. and Rady, M.M. Presoaking application of propolis and maize grain extracts alleviates salinity stress in common bean (Phaseolus vulgaris L.). Scientia Horticulturae, 2014, 168: 210-217. 
50. Habib, N.; Ashraf, M.; Ali, Q. and Perveen, R. Response of salt stressed okra (Abelmoschus esculentus Moench) plants to foliar-applied glycine betaine and glycine betaine containing sugarbeet extract. South African Journal of Botany, 2012, 83: 151-158.

$* * * * * \quad * * * * *$ 